\title{
Assessment of the physicochemical qualities of groundwater and soils around oil-producing communities in Afam, area of Porthacourt, Niger Delta Nigeria
}

\author{
Ogbonnaya Igwe ${ }^{1} \cdot$ Moses Ngwoke ${ }^{1} \cdot$ Bernadette U. Ukah ${ }^{1}$ (I) $\cdot$ Oyem E. Ubido ${ }^{1}$
}

Received: 14 July 2020 / Accepted: 22 March 2021 / Published online: 10 April 2021

(C) The Author(s) 2021

\begin{abstract}
Results from the assessment of physicochemical qualities of groundwater and soils around Afam in Niger Delta done using, statistical model, geo-accumulation indices (I-geo) and water quality indices showed that $\mathrm{pH}$ and $\mathrm{Cu}$ did not correlate strongly with any of the parameters analyzed in the study area. At 2-tailed of 0.05 levels of significance, moderate correlation exist between dissolved oxygen and $\mathrm{Ca}>\mathrm{Na}$, strong to moderate correlation exist between temperature and total dissolved solids (TDS) $>$ E.C $>\mathrm{Na}$ and $\mathrm{Ca}$, whereas at 2-tailed level of 0.02, very strong correlation exist between E.C and TDS (0.988), $>\mathrm{Na}$ (0.966), $>\mathrm{Ca}(0.957)$. TDS in turn is strongly correlated with $\mathrm{Na}(0.987),>\mathrm{Ca}(0.972) . \mathrm{Fe}, \mathrm{Zn}, \mathrm{Pb}$ and $\mathrm{Cr}$, total petroleum hydrocarbon (TPHC), oil and grease $(\mathrm{O} \& \mathrm{G})(<0.001 \mathrm{mg} / \mathrm{l})$ did not correlate with any of the physicochemical elements in the samples. At 2-tailed levels of 0.02 and 0.05 , no significant correlation exists between alkalinity and salinity in groundwater samples and also with any the elements. Groundwater showed excellent water quality except one (62.307). pH, $\mathrm{Cr}, \mathrm{Fe}, \mathrm{Ni}$, $\mathrm{Pb}$ and $\mathrm{Cu}$ in the soil were unpolluted since I-geo values are less than 1. Polycyclic aromatic hydrocarbon (PAH) (2.5194) showed low pollution, O\&G (3.8886) showed moderate pollution, while total hydrocarbon content (THC) (6.2069), total organic carbon (TOC) (7.4919) and TPHC (9.4851) showed extreme pollution. The control site appeared to be unpolluted except TOC (6.8721). Percentage of clay particles in the soil is higher than in control.
\end{abstract}

Keywords Correlation coefficient $\cdot$ Heavy metals $\cdot$ Geo-accumulation indices (1-geo) $\cdot$ Petroleum components $\cdot$ Water quality indices (WQI) $\cdot$ Soil particle size distribution

\section{Introduction}

There are varieties of pollutants affecting soil and groundwater such as heavy metals, crude oil which predominantly consist of total petroleum hydrocarbon (TPH), the polycyclic aromatic hydrocarbon (PAH), and the volatile aromatics, benzene, toluene, ethyl benzene and xylene (BTEX)

Bernadette U. Ukah

ukahbernadette@yahoo.com

Ogbonnaya Igwe

ogbonnaya.igwe@unn.edu.ng

Moses Ngwoke

moses.ngwoke@shell.com

Oyem E. Ubido

oyememmanuel@yahoo.com

1 Department of Geology, University of Nigeria, Nsukka, Nigeria
(Osuji et al. 2006), and other effluents resulting from the anthropogenic activities. Of environmental concern is the toxicity of these components due their carcinogenic effect especially BTEX because, contaminants may travel a great distance and affect a large portion of the environment before pollution is recognized (Toro et al. 2007). Most often these effluents come into the environment through accidents, oil spillage, urban input, industrial releases and commercial or domestic uses (Richard and David 1970; Ou et al; 2004). Salt water intrusion resulting from excessive abstraction of groundwater is another source of groundwater contamination, and this is prevalent in Niger Delta due to nearness of groundwater to coastal marine water body as well human activities (Ngah 2009). According to Egbe and Thompson (2010), oil spills are source of heavy metal which shows significant mobility in soil, contaminating aquatic and terrestrial environments, especially in oil-producing regions. Osuji and Onojake (2004) reported that crude oil polluted soil show high total organic content after six months of the 
pollution. These effluents, be it by accident or vandalization causes deleterious effect on plant growth, soil macronutrients, microorganism, aquatic and the terrestrial ecosystem and importantly groundwater system (Mukherjee and Bordoloi 2010; Gayathiri et al. 2017). Once groundwater is polluted, it takes many years before it can be redeemed (Ukah et al. 2018). Excellent water quality is an essential necessity for the sustainability of healthy environmental growth and development. The assessment of groundwater quality often time seems incomplete without soil quality assessment because once the soil is contaminated; the groundwater is usually affected through natural exchange processes existing between the soil and the groundwater (Keller 2011; Ukah et al. 2018).

However, this study focused on the assessment of both groundwater and soil quality around oil-producing communities in Afam area of Porthacourt, Niger Delta Nigeria. Port Harcourt in particular is the second largest sea ports in Nigeria thus the uncontrolled rapid population/urbanization resulting to excessive pressure on both water system and land use activities. Afam is among the areas in Port Harcourt that has been urbanized mostly by the oil-producing communities who not only operate but also reside there. There is scanty literature to ascertain the speculation about contamination free soil and good groundwater resource around Afam. The study therefore assessed the physicochemical qualities of the soil and groundwater in this area using water quality index (WQI), geo-accumulation index and Pearson correlation coefficient.

\section{Geological setting and climatic condition of the study area}

\section{Physiographical/geological setting of the study area}

Niger Delta the key oil-producing province in Nigeria with its characteristics network of rivers and creeks which drain the hinterland, transporting both water and sediments to the Atlantic Ocean harbors several oil and gas industries (Nduka et al. 2008; Nduka and Orisakwe 2011). It consists of present-day Bayelsa, Delta, Rivers, Abia, Akwa-Ibom, Cross River State, Edo, Imo and Ondo States. Lithostratigraphically, Niger Delta sedimentary basin is divided into the oldest Akata formation (Paleocene), the Agbada formation (Eocene) and the youngest Benin formation (Miocene to Recent) (Reyment 1965; Short and Stouble 1967; Murat 1970; Merki 1970; Nwankwoala and Walter 2012). Afam area of Porthacourt in Rivers state, Niger Delta Nigeria lies in Latitudes $4^{\circ} 47^{\prime} 55.68^{\prime \prime} \mathrm{N}$ and Longitudes $7^{\circ} 00^{\prime}$ 7.2" E (Fig. 1) of the northeastern part of Portharcourt state (Fig. 1). Geologically, Afam is sitting on Afam clay member of Benin formation which is interpreted to be an ancient valley fill formed in Miocene sediments (Fig. 1). The lithic fill of the Afam channel is dominated by clay beds with localized development of sand bodies in time and space (Short and Stouble 1967).
Fig. 1 Geology of the study area

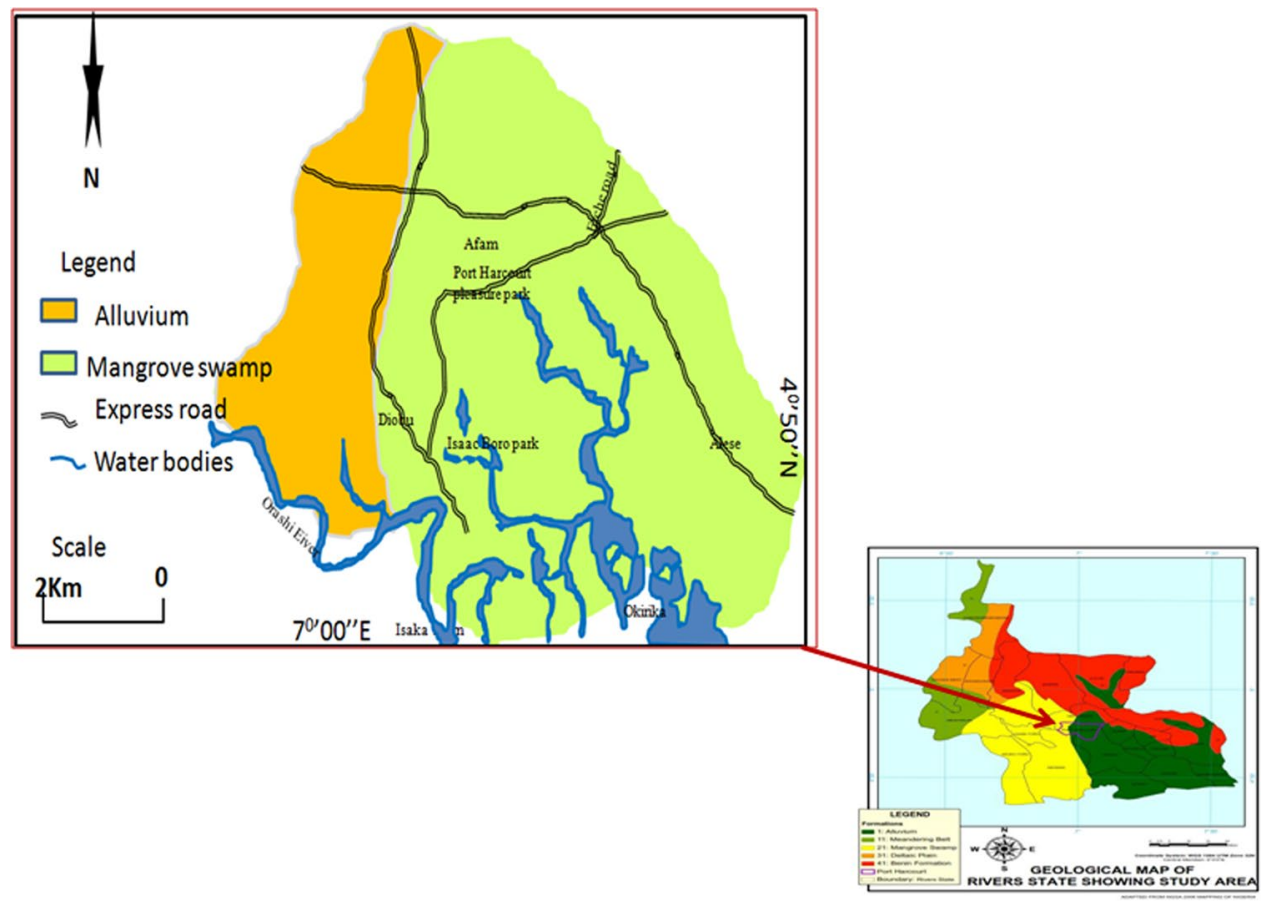




\section{Climatic condition of the study area}

The Port Harcourt lies on $9 \mathrm{~m}$ above sea level with a tropical climate considered to be Am according to the KöppenGeiger climate classification (Koppen 1900). It has average annual temperature of $26.4{ }^{\circ} \mathrm{C}$ and rainfall of about $2500 \mathrm{~mm}$ (Akintola 1986). The driest month is January, warmest month is February, and the coldest month is August, while most of the rain here falls in September, averaging $414 \mathrm{~mm}$. The area experience heavy rain fall from March to October and even the dry months of November, December, January and February are not free from occasional rainfall (Gobo 1990). During extensive rainfall, and the consequent reduction in the infiltration capacity of the soil due to its low permeability, flooding is commonly experienced in most homes.

\section{Materials and methodology}

\section{Sample collection}

Due to strict accessibility of the study area and few numbers of boreholes that are free from water treatment, eight samples each and four control samples making a total of twelve groundwater samples and twelve soil samples of soil, respectively. These were systematically collected, eight (8) represent the samples from oil producing communities in Afam and four samples outside the oil producing communities (zone with lesser environmental pressure and oil activities) as control samples. Soil samples were collected at two different depths of $0-15 \mathrm{~cm}$ (top layer) and $15-30 \mathrm{~cm}$ (second layer) with respect to distance using a Dutch soil auger. The samples were immediately on collection placed in cellophane bags, tightly tied and labeled using a masking tape and marker pen. Prior to the field sampling, 1-L sampling plastic bottles were prewashed and sterilized. At each sampling location, the sampling bottles were rinsed using the source water to be sampled. These samples upon collection were placed carefully in an ice-crested cooler to avoid atmospheric reaction before laboratory analysis.

The physicochemical parameters determined from the soil samples were temperatures, oil and grease $(O \& G)$, particle size distribution of soil, $\mathrm{pH}$, total petroleum hydrocarbon (TPHC), total hydrocarbon content (THC), total organic carbon (TOC), polycyclic aromatic hydrocarbon (PAH), benzene toluene ethyl benzene and xylene (BTEX), cations ( $\mathrm{Ca}$, and $\mathrm{Na}$,) and heavy metals such as $\mathrm{Ni}, \mathrm{Pb}, \mathrm{Hg}, \mathrm{As}, \mathrm{V}, \mathrm{Ba}$, $\mathrm{Cu}, \mathrm{Fe}, \mathrm{Mn}$ and $\mathrm{Zn}$. In groundwater samples, the following parameters were determined; turbidity, salinity, alkalinity,
EC, O\&G, total dissolved solids (TDS), dissolved oxygen (DO), TPHC, cations and heavy metals tested in the soil samples.

\section{Determination of physicochemical parameters in groundwater and soil samples}

The heavy metals $\mathrm{Cr}, \mathrm{Fe}, \mathrm{Zn}, \mathrm{Cu}, \mathrm{Mn}$ and $\mathrm{Pb}$ were analyzed in groundwater samples while $\mathrm{Hg}, \mathrm{Ba}, \mathrm{Vd}, \mathrm{Fe}, \mathrm{Zn}$, $\mathrm{Cr}, \mathrm{Cd}, \mathrm{Cu}, \mathrm{Mn}, \mathrm{Pb}, \mathrm{As}$ and $\mathrm{Ni}$ were analyzed for each of soil samples using specific hollow cathode lamp at a specific wavelength and then aspirated into the flame of atomic absorption spectrophotometer (AAS, PerkinElmer Analyst 200) using air acetylene flame for the metal analysis against standard metal solutions.

Total dissolved solids (TDS), all the water samples were standardized with $342 \mathrm{ppm}$ sodium chloride calibration solution, measured using portable combined electrical conductivity/TDS/temperature meter (HM Digital COM100). The temperature values of the samples were recorded using a thermometer while $\mathrm{pH}$, salinity and electrical conductivity was determined using Hand-held pH/Electrical conductivity instrument (ExStik II EC500 model).

DO in the water samples were determined by using Winkler Method of Incubation technique, while the metal content in water and sample was analyzed using Atomic Absorption Spectrophotometer (Buck Scientific Model 210 VGP).

The Cations (Ca and $\mathrm{Na}$ ): An ion chromatography (IC) method was used for the determination of the cations in the water samples $\left(\mathrm{Na}^{+}\right.$and $\left.\mathrm{Ca}^{2+}\right)$ using a single pump, a single eluent of $1.0 \mathrm{mM}$ trimellitic acid (pH 2.94) and a single detector. The 10-port valve was switched for the separation of cations in a single chromatographic run (Mahmood et al. 2020). In the case of soil, water extraction is the best procedure to be used. First precise weights of soil sample were mixed with a certain volume of deionized water and with continuous mixing the available ions were transferred into the water. The solution is separated by filtration and washing the residual soil with two or three fraction of water. The water fraction is combined with the filtrate. The whole solution must be completed to 100 or $250 \mathrm{~mL}$ and analyzed by IC for the ion concentration (Anoop and Debashish 2020).

Alkalinity: the alkalinity of the water samples were determined by titrimetric method. Here, three drops of phenolphthalein indicator were added to $50 \mathrm{~mL}$ water sample and titrate with $0.02 \mathrm{~N}$ sulfuric acid to $\mathrm{pH} 8.3$ and estimate phenolphthalein alkalinity (phenolphthalein indicator will change color, from pink to clear, at $\mathrm{pH}$ 8.3). 
The oil/grease: the presence of oil and grease in both groundwater and soil samples were determined using US EPA method 9071A (1994) with reported limit of $50 \mathrm{ppm}$.

The TPH/TPHC were measured by EPA method 8015B gas chromatography/flame ionization detection (GC/FID) with reported method of limit $10 \mathrm{ppm}$ for soil/sediment and water (US EPA method 8015B).

BTEX: The gas chromatography-mass spectrometry (GC/MS) method $8020 \mathrm{~B}$ was used for analysis of BTEX in soil samples.

THC was obtained through spectrophotometric method by oven- drying $1 \mathrm{~g}$ of soil sample and total hydrocarbon content extracted with chloroform; then its concentration measured using spectrophotometer.

The extraction of PAHs from the soil was carried out in a soxhlet apparatus with $100 \mathrm{ml}$ methylene-Chloride for $24 \mathrm{~h}$ which was reduced to $2 \mathrm{ml}$ and dissolved in cyclohexane to $5 \mathrm{ml}$ volume. The resulting extract was analyzed using HP 5870 gas chromatograph. TOC was measured using ascorbic acid method.

\section{Determination of particle size distribution of the soil}

Particle size distribution of the soil samples was determined in the laboratory in accordance with specifications in the British Standards (BS) 5930 (1981), 8004 (1986) and American Society for Testing and Materials (ASTM) Designation 2487 (2011), for soil classification.

\section{Water quality indexing (WQI)}

WQI is commonly used for the detection and evaluation of water pollution and possible range of uses (Table 1). In this study, eleven water parameters were selected based on its direct involvement in deteriorating water quality for human consumption. The method adopted by Li et al. (2010), Wu et al. (2011) and Ukah et al. (2019a) was used in order to determine the WQI of the groundwater samples.

Table 1 WQI classification scheme for groundwater and possible ranges of use (Brown et al.1972; Ukah et al 2019a)

\begin{tabular}{lll}
\hline WQI & Water quality & Possible ranges for uses \\
\hline $0-25$ & Excellent & Drinking, irrigation and industrial \\
$25-50$ & Good & Domestic, irrigation and industrial \\
$51-75$ & Fair & Irrigation and industrial \\
$76-100$ & Poor & irrigation \\
$101-150$ & Very poor & Restricted use for irrigation \\
$>150$ & Unfit for drinking & Proper treatment required before use
\end{tabular}

World Health Organization (2017) standard values were considered for computation of rating and unit weight (wi). Relative weights ranging from 1 to 5 were assigned to the physicochemical parameters in the quality of water for drinking, irrigation and industrial purposes. With the assigned weights, the relative weight of each parameter was calculated using the formula:

$Q_{i}=\left(C_{i} / S_{i}\right) \times 100$,

where $Q_{i}$ is quality rating, $C_{i}$ is the concentration of each parameter, and $S_{i}$ is the standard value for the parameter.

$W i=w i / \sum_{i=1}^{n} w i$,

where $W_{i}$ is relative weight, $w_{i}$ is weight of parameter, and $n$ is the total number of parameters.

WQI is the summation of all sub-indices for each sample, as shown in Eqs. 3 and 4, respectively.

$S I_{i}=W_{i} \times Q_{i}$

$W Q I=\sum S I_{i-n}$

where $S I_{i}$ is the sub-index of $i$ th parameter, $\mathrm{Q}_{\mathrm{i}}$ is the quality rating based on concentration of $i$ th parameter and $n$ is the number of parameters.

\section{Geochemical accumulation index (I-geo)}

$1-$ geo $=\log _{2}(C n / 1.5 B n)$,

where $\mathrm{Cn}$ is the concentration of the metal pollutant, $\mathrm{Bn}$ is the geochemical background concentration of the pollutant in soil, and 1.5 is the background matrix correction factor due to lithogenic effect. In this study, DPR (2002) standard was adopted for metal concentration in the soil.

Muller (1969) consists of five classes ranging from unpolluted to extremely polluted: I-geo $<1$ unpolluted, $1 \leq$ I-geo $<2$ indicates low pollution, $3 \leq$ I-geo $<4$ moderately polluted, $4 \leq$ Igeo $<5$ strongly polluted, and I-geo $<5$ is extremely polluted.

\section{Statistical model}

SPSS (Statistical Package for the Social Sciences) for Windows, version 23.0 was used for the discriminate analysis (correlation) of the data. Significant level of two-tailed test of 0.01 and 0.05 of Pearson correlation coefficients, greater than $0.7,0.5<r<0.7$ and less than 0.5 were considered as strong, moderate, and weak correlation, respectively (Soltani et al.2017; Ukah et al. 2019a, 2020b). 


\section{Results and discussion}

\section{Physicochemical qualities of groundwater in the study area}

Physicochemical qualities of groundwater samples in the study is summarized in Table 2 below.

\section{pH quality of groundwater samples}

Concentration values for the $\mathrm{pH}$ in water samples range from 6.8 to 6.9 while the control samples range from 6.0 to 7.1 , both sample fall within the WHO permissible limit of 6.5-8.5 for drinking water except Bcrrl2 (Table 2). $\mathrm{pH}$ usually has no direct impact on consumers but, it is important operational water quality parameters because it is an indicator of increasing pollution. Low water $\mathrm{pH}$ (approximately $\mathrm{pH} 7$ or less) is more likely to be corrosive. The $\mathrm{pH}$ of the water entering the distribution system must be controlled to minimize the corrosion of water pipes in household water systems, less it result to contamination of drinking water and adverse effects on its taste and appearance (Dieter et al. 2018). Statistically, pH did not correlate strongly with any of the parameters analyzed in Table 3.

\section{Temperature, electrical conductivity (E.C), total dissolved solid (TDS) and dissolved oxygen (DO)}

Although DO in Bctrl1 is higher than the rest samples, but DO levels in all the samples were quite below permissible limit and cannot support the activities of aerobic organism in the study area. This might upset the ecosystem thereby encouraging the development of septic condition and subsequently produce anaerobic condition in the groundwater (Nwachukwu and Osuagwu 2014). Moreover, water saturated in oxygen tastes fresh to human palates but high DO levels speed up corrosion in water pipes. This is why industries used water with least amount of DO (Lenntech 2017). If water previously is unpolluted, the water will be saturated with dissolved oxygen (DO), or nearly so, and the bacteria present in the water will be aerobic types. At 2-tailed significant level of 0.05 , moderate correlation exist between DO and $\mathrm{Ca}>\mathrm{Na}$, which shows that the presence of these cations affect the concentration of DO in water. According to WHO standard, there is no permissible limit for the degree of temperature in water. Both water samples (i.e., the sampling site and the control) have slight differences in temperature concentration (Table 2). At 2-tailed level of 0.05 significant, strong to moderate correlation exist between temperature and TDS $>$ E.C $>\mathrm{Na}$ and $\mathrm{Ca}$. Although EC of water samples was lower $(58.8-74.0 \mu \mathrm{S} / \mathrm{cm})$ than in control (118.4-138.4 $\mu \mathrm{S} / \mathrm{cm}$ ), both samples are within WHO permissible limit of $400 \mu \mathrm{S} / \mathrm{cm}$. Water in its pure form is not a good conductor of electricity just like distilled water which has lower EC than groundwater. Organic compounds like oil do not form ions that conduct electricity unlike the cations ( $\mathrm{Na}$ and Ca).(Fondriest Staff 2010). According to Edema (2012) the presence of oil spill in water decreases EC. Statistically at 2-tailed level of 0.02 , very strong correlation exist between E.C and TDS (0.988), $>\mathrm{Na}(0.966),>\mathrm{Ca}(0.957)$. TDS in turn is strongly correlated with $\mathrm{Na}(0.987),>\mathrm{Ca}(0.972)$ at 2-tailed level of 0.02 significant. The strong correlation existing between EC, TDS and these cations further defines E.C as a function of the amount of dissolved solid in water. Thus, it measures the ionic activity of a solution in terms of its ability to transmit current while TDS is a measure of total ion dissolved in a solution. TDS in water samples ranged from 29.4 to $37.0 \mathrm{mg} / \mathrm{l}$ and in control from 67.1 to $69.1 \mathrm{mg} / \mathrm{l}$. and both are within WHO permissible limit of 500-1500 (Table1). Higher TDS observed in the control might be due to anthropogenic activities like farming around the area.

\section{Turbidity, salinity and alkalinity}

Turbidity values for the water samples range from 0.01 to 30.6 NTU while the control ranged from 7.9 to 8.2 NTU. Only two of the eight (8) water samples (BH2, BH6) and the control (7.90-8.20 NTU) exhibit highest turbid values thus, exceeding the WHO permissible limit of 5.0 NTU (Table 1). Excess turbidity just as in $\mathrm{BH} 2$ and $\mathrm{BH} 6$ can lead to staining of materials, fittings and clothes exposed during washing. It doesn't have health implication in terms of its excessiveness in drinking water. There is no WHO permissible limit for salinity and alkalinity in drinking water. Salinity of the groundwater samples ranged from 5.64 to $8.47 \%$ which is the same as the control. Alkalinity of the water samples ranged from 9.3 to $18.6 \%$ and in the controls (9.3\%). Moreover, in Niger Delta, high salinity of groundwater is too prevalent due to salt intrusion from the nearest marine body (Ngah 2009). At 2-tailed levels of 0.02 and 0.05, no significant correlation exists between alkalinity and salinity of the water samples and also with any of the physicochemical parameters in the water samples. In other words, groundwater salinity or alkalinity is the function of nearness of the coastal system and over abstraction of the groundwater due to human activities (Ngah 2009).

\section{TPHC and oil and grease}

The concentration of TPH, oil and grease in the groundwater samples are insignificant, $(<0.001 \mathrm{mg} / \mathrm{l})$ in (Table 2$)$ thus do not correlate with any of the physicochemical elements in the samples (Table 3). 


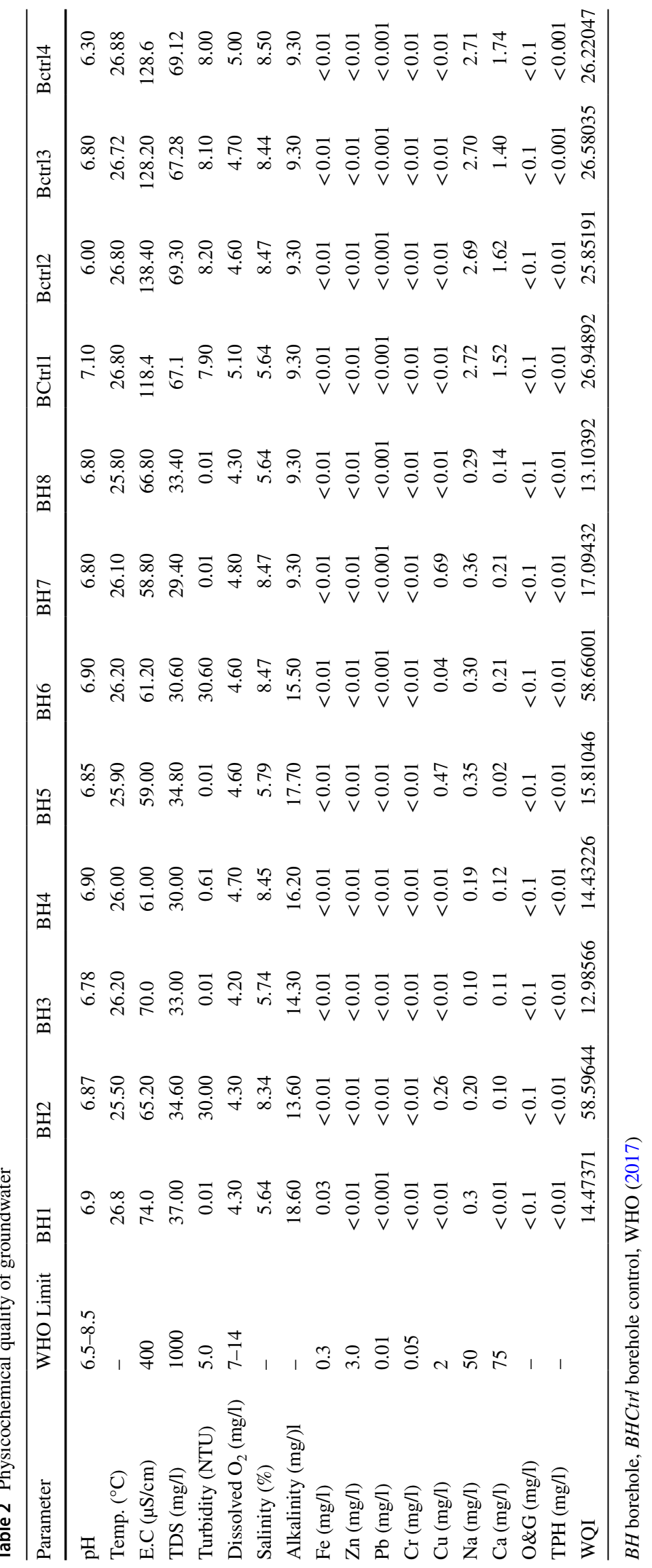




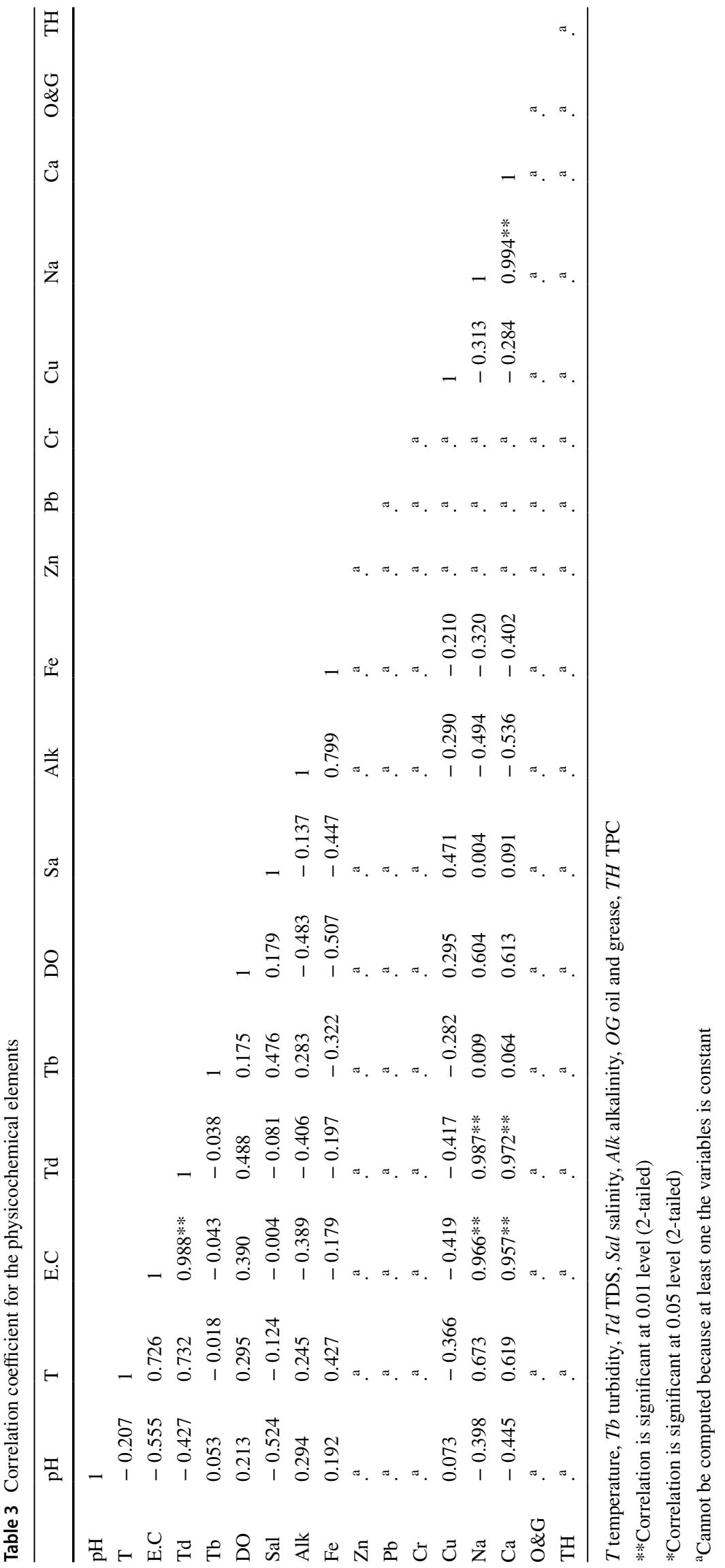




\section{Heavy metals}

The concentration of $\mathrm{Fe}, \mathrm{Zn}, \mathrm{Pb}$ and $\mathrm{Cr}$ in the water samples and the control were of the same $(<0.001 \mathrm{mg} / \mathrm{l})$ and also lower than the WHO permissible limit (Table 2). While Zn, $\mathrm{Pb}, \mathrm{Cr}$ cannot be computed because at least one of the variables is constant and thus they do not correlate with any of the elements in the samples.

The concentration of copper in the water samples occur in the range of $<0.01-0.69 \mathrm{mg} / \mathrm{l}$ while the control is $<0.01 \mathrm{mg} / \mathrm{l}$. Higher concentration of copper $(0.04$ and $0.69 \mathrm{mg} / \mathrm{l}$ ) was observed in $\mathrm{BH} 7$ even though it is still within the WHO permissible limit of $2 \mathrm{mg} / \mathrm{l}$ for copper in drinking water. Based on statistic, no significant strong correlation exists between $\mathrm{Cu}$ and any of the physicochemical parameters in Table 3.

\section{Cations}

$\mathrm{Ca}$ is one of the major dietary requirements for humans $(0.3-0.5 \mathrm{~g} /$ day $)$. It is the major constituent of hardness in water. In the analysis (Table 2), Ca ranged from $<0.01$ to $0.21 \mathrm{mg} / \mathrm{l}$ while in the control, it ranged from 1.40 to $1.74 \mathrm{mg} / \mathrm{l}$ but the control values were reasonably higher than the main samples. There is no permissible limit for Ca. Sodium ranged from 0.10 to $0.36 \mathrm{mg} / \mathrm{l}$ for the main water sample while the control ranged from 2.69 to $2.72 \mathrm{mg} / \mathrm{l}$ which is higher than the water sample. This could be attributed to farming activities in the area. Both samples are within the WHO permissible limit for $\mathrm{Na}$ in drinking water. At 2-tailed significant level of 0.02 ; $\mathrm{Na}$ and $\mathrm{Ca}$ strongly correlate with each other and also with E.C and turbidity, while, at 0.05 level of significant; $\mathrm{Na}$ and $\mathrm{Ca}$ correlate moderately with temperature (Table 3 ) suggesting that the more concentrated the ions in water, the higher the $\mathrm{EC}$ and vise versa (Chang et al. 1983).
WQI

The groundwater quality in the study area was classified using the WQI classification scheme (Table 1). Two (BH2, 58.596 and BH6, 58.660) out of the eight (8) water samples (i.e., $25 \%$ of the samples tested) show fair water quality based on the WQI classification scheme, suggesting that $\mathrm{BH} 2$ and $\mathrm{BH} 6$ can only be used for irrigation and industrial purposes and not for drinking (Table 1). However $75 \%$ of the groundwater samples tested fall within the range (13.10-17.00) of excellent water quality (Table 1 and Fig. 2). This implies that these six (6) water samples from the study site (Afam) can be used for drinking, irrigation as well as industrial purposes. Nevertheless, four of the control samples though collected from areas of lesser environmental pressure only fall within good water quality in the WQI classification scheme (Table 1 and Fig. 2). The control samples are good for domestic, irrigation and industrial purposes (Brown et al.1972; Ukah et al. 2019a, 2020a).

\section{Physicochemical qualities of soil in the sampled areas}

\section{pH and EC}

As observed in groundwater, $\mathrm{pH}$ and $\mathrm{EC}$ concentration in soil are lower in active soils (i.e., soils from the area of study) than in control and decreased with depth in both soils (Table 4). pH does not have adverse effect on plant growth even though both soils are within the permissible limit in terms of DPR (2002) pH standard (Gentili et al. 2018). EC reflects the sum of salts and ions in the soil solution (Bronson et al. 2005; Sudduth et al. 2005; Peralta and Costa 2013). It also tells much more about the physical structure and health of the soil, though, and can help to indirectly measure crop productivity. EC concentrations in control soils were higher than in active soil both at the
Fig. 2 WQI of the groundwater samples

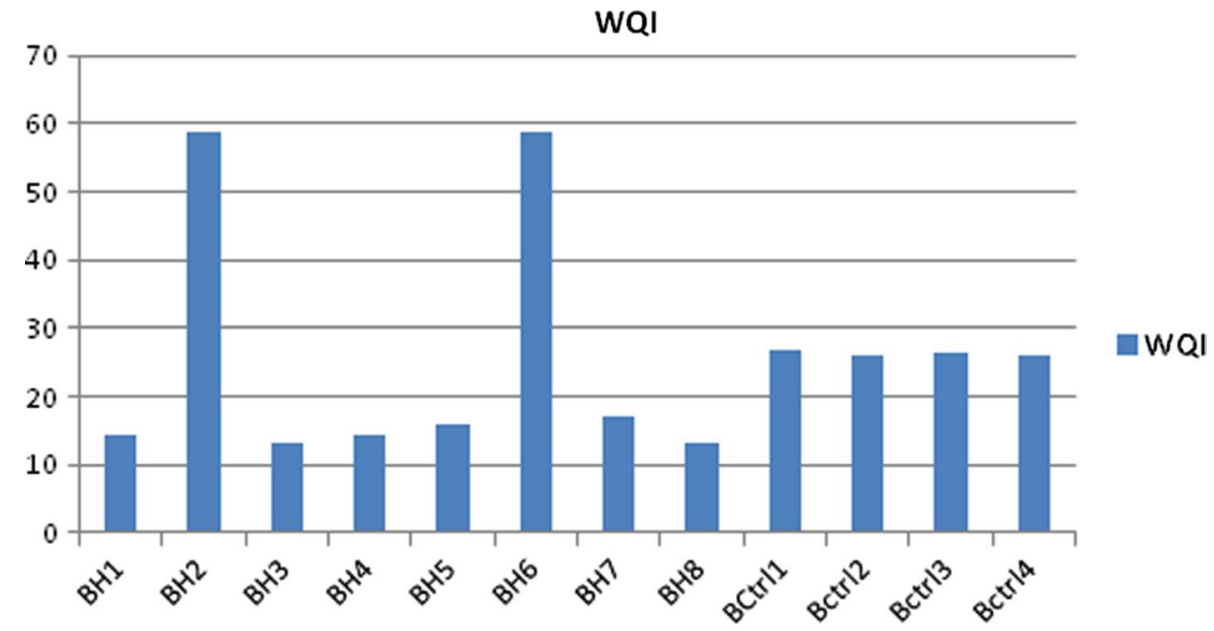


Table 4 Physicochemical quality of soil samples in study area

\begin{tabular}{|c|c|c|c|c|c|c|}
\hline Parameter & Depth $(\mathrm{cm})$ & Active soil (mean) & I-geo & Control mean & DPR (2002) & I-geo \\
\hline \multirow[t]{2}{*}{$\mathrm{pH}$} & $0-15$ & 6.12 & -0.6719 & 6.21 & 6.5 & -0.6508 \\
\hline & $15-30$ & 6.02 & & 6.02 & & \\
\hline \multirow[t]{2}{*}{ TOC $(\%)$} & $0-15$ & 1.89 & 7.4919 & 1.23 & 0.007 & 6.8721 \\
\hline & $15-30$ & 1.89 & & 1.02 & & \\
\hline \multirow[t]{2}{*}{$\mathrm{EC}(\mu \mathrm{S} / \mathrm{cm})$} & $0-15$ & 130.4 & & 156 & - & \\
\hline & $15-30$ & 119.2 & & 134 & & \\
\hline \multirow[t]{2}{*}{ BTEX } & $0-15$ & $<0.01$ & 0 & $<0.01$ & 0.05 & 0 \\
\hline & $15-30$ & $<0.01$ & & $<0.01$ & & \\
\hline \multirow[t]{2}{*}{ PAH } & $0-15$ & 8.6 & 2.5194 & $<0.1$ & 1 & 0 \\
\hline & $15-30$ & 9.8 & & $<0.1$ & & \\
\hline \multirow[t]{2}{*}{ THC } & $0-15$ & 110.8 & 6.2069 & $<0.01$ & 1 & 0 \\
\hline & $15-30$ & 1.27 & & $<0.01$ & & \\
\hline \multirow[t]{2}{*}{ TPHC (mg/kg) } & $0-15$ & 1075 & 9.4851 & $<0.01$ & 1 & 0 \\
\hline & $15-30$ & 1230.9 & & $<0.01$ & & \\
\hline \multirow[t]{2}{*}{ O\&G (mg/L) } & $0-15$ & 1110.8 & 3.8886 & $<0.1$ & 50 & 0 \\
\hline & $15-30$ & 1271.9 & & $<0.1$ & & \\
\hline \multirow[t]{2}{*}{$\mathrm{Na}(\mathrm{mg} / \mathrm{L})$} & $0-15$ & 397.28 & & 370.5 & - & \\
\hline & $15-30$ & 398.28 & & 390 & & \\
\hline \multirow[t]{2}{*}{$\mathrm{Ca}(\mathrm{mg} / \mathrm{kg})$} & $0-15$ & 206 & & 67.145 & 75 & \\
\hline & $15-30$ & 225 & & 71.14 & & \\
\hline \multirow[t]{2}{*}{$\mathrm{Cr}(\mathrm{mg} / \mathrm{kg})$} & $0-15$ & 8.92 & -4.0718 & $<0.01$ & 100 & 0 \\
\hline & $15-30$ & $<0.01$ & & $<0.01$ & & \\
\hline \multirow[t]{2}{*}{$\mathrm{Cd}$} & $0-15$ & $<0.01$ & - & $<0.01$ & 0.8 & - \\
\hline & $15-30$ & $<0.01$ & - & $<0.01$ & & \\
\hline \multirow[t]{2}{*}{$\mathrm{Mn}$} & $0-15$ & - & - & 0 & 437 & - \\
\hline & $15-30$ & - & & 0 & & \\
\hline \multirow[t]{2}{*}{$\mathrm{Fe}$} & $0-15$ & 1028 & -2.8670 & 1007.5 & 5000 & -2.8961 \\
\hline & $15-30$ & 1015 & & 1015 & & \\
\hline \multirow[t]{2}{*}{$\mathrm{Ba}$} & $0-15$ & $<0.01$ & 0 & $<0.01$ & 200 & 0 \\
\hline & $15-30$ & $<0.01$ & & $<0.01$ & & \\
\hline \multirow[t]{2}{*}{$\mathrm{Ni}$} & $0-15$ & 11.64 & -2.1732 & 2.145 & 35 & -4.6133 \\
\hline & $15-30$ & 9.46 & & 1.13 & & \\
\hline \multirow[t]{2}{*}{$\mathrm{Pb}$} & $0-15$ & 2.67 & -5.5775 & $<0.01$ & 85 & 0 \\
\hline & $15-30$ & 0.154 & & $<0.01$ & & \\
\hline \multirow[t]{2}{*}{$\mathrm{Cu}$} & $0-15$ & 8.9 & -2.6011 & $<0.01$ & 36 & 0 \\
\hline & $15-30$ & 8.9 & & $<0.01$ & & \\
\hline \multirow[t]{2}{*}{$\mathrm{Zn}$} & $0-15$ & $<0.01$ & 0 & $<0.01$ & 140 & 0 \\
\hline & $15-30$ & $<0.01$ & & $<0.01$ & & \\
\hline \multirow[t]{2}{*}{ As } & $0-15$ & $<0.01$ & 0 & $<0.01$ & 29 & 0 \\
\hline & $15-30$ & $<0.01$ & & $<0.01$ & & \\
\hline \multirow[t]{2}{*}{$\mathrm{Hg}$} & $0-15$ & $<0.01$ & 0 & $<0.01$ & 0.3 & 0 \\
\hline & $15-30$ & $<0.01$ & & $<0.01$ & & \\
\hline \multirow[t]{2}{*}{$\mathrm{Vd}$} & $0-15$ & $<0.01$ & & $<0.01$ & - & \\
\hline & $15-30$ & $<0.01$ & & $<0.01$ & & \\
\hline
\end{tabular}

upper and lower layer of the soil and DPR (2002) does not have permissible limit for EC concentration in soil. As EC increases, more attention to water management is needed to prevent salinity from adversely affecting plants (Rabenberg and Kniffen 2014).

\section{PAH, TPHC, THC, oil \& grease, TOC and BTEX}

Oil and grease in the active soil show increase in concentration from 0 to $15 \mathrm{~cm}$ downward but in control it was insignificant. The presence of oil and grease in the soil are readily 
contaminable due to infiltration from the surface layer into the water bearing layer (Anderson et al. 1993). In the active soil, PAH and TPHC concentration increased downward with depth but in control no significant value was recorded. PAH in soil causes interference with associate anaerobic and hydrophilic condition in plants (Racine 1994). THC in active soil decreased drastically with depth from 1.27 to $110.8 \mathrm{mg} /$ $\mathrm{kg}$ while in control no significant value was recorded. THC has not gotten deeper into the soil like TPHC and O\&G. PAH, TPHC. THC, oil and grease can reduce germination of seeds (Bona et al. 2011). These are evidence that industrial effluent has impacted negatively on the soil since these four (PAH, TPHC. THC, oil and grease) are the major constituent of crude oil (Osuji et al. 2006). However, TOC concentration remains the same, $1.89 \%$ in upper and lower layer of the active soil unlike in control where it decreases with depth. Crude oil contaminants or oil spillage contributes to TOC in the soil because of much higher TPHC concentration (Wang et al. 2009). Just as in DO concentration in water, oil constituents also cause anaerobic environment in soil by asphyxiating soil particles and obstructing air diffusion in soil pores hence impringing on the soil microbial communities and destruction of vegetations (Sutton et al. 2013; Labud et al. 2007; Townsend et al. 2003).

\section{Cations and heavy metals quality of the soil}

The concentration of cations $\mathrm{Na}$ and $\mathrm{Ca}$ increased with depth from 0 to $15 \mathrm{~cm}$ through $15-30 \mathrm{~cm}$ in the active and control soil samples and were higher in active soil than in control (Table 4). Alternatively in groundwater, higher concentration of $\mathrm{Ca}$, and $\mathrm{Na}$ occurred in control. Cation exchange capacity is a direct contribution from the clay and organic matter content of the soil which logically is a function of the geology. Unlike the cation, heavy metals like $\mathrm{Cr}, \mathrm{Fe}, \mathrm{Ni}$ and $\mathrm{Pb}$ decrease with depth from the top layer $(0-15 \mathrm{~cm})$ through second layer $(15-30 \mathrm{~cm})$ in both soils with the exception of $\mathrm{Fe}$ in the control $(1007.5 \mathrm{mg} / \mathrm{k}$ for the first layer and $1015 \mathrm{mg} / \mathrm{k}$ for second layer). However, $\mathrm{Cr}, \mathrm{Fe}, \mathrm{Ni}$ and $\mathrm{Pb}$ are highly concentrated in active soil than in control unlike in groundwater were the value for the metals were the same (i.e., insignificant). The following metals such as $\mathrm{Cu}, \mathrm{Zn}$, $\mathrm{Cd}, \mathrm{Mn}, \mathrm{Ba}, \mathrm{As}, \mathrm{Hg}$ and $\mathrm{Vd}$ are insignificant $(<0.01 \mathrm{mg} / \mathrm{k})$ in active soil and control except for $\mathrm{Cu}$ whose concentration value $(8.9 \mathrm{mg} / \mathrm{k})$ remained the same at various depths in the active soil (Table 4). In groundwater, presence of $\mathrm{Cu}$ was also felt but was insignificant in the control. Mn was absent in both samples (Table 4).

\section{Geo-accumulation index (I-geo)}

I-geo was calculated using the concentration of the following physicochemical parameters from the top layer of both soils pH, PAH, THC, TPHC, TOC, O\&G, $\mathrm{Cr}, \mathrm{Fe}, \mathrm{Ni}, \mathrm{Pb}$ and $\mathrm{Cu}$ using DPR (2002) permissible limit as the background value (Table 4). I-geo classification scheme adopted by Muller (1969) and Ukah et al. (2018) showed pH, Cr, Fe, $\mathrm{Ni}, \mathrm{Pb}$ and $\mathrm{Cu}$ in the active site to be unpolluted since I-geo values are less than 1 (Fig. 3). PAH (2.5194) showed low pollution, O\&G (3.8886) showed moderate pollution, while THC (6.2069), TOC (7.4919) and TPHC (9.4851) showed extreme pollution (Table 4, Fig. 3). This result also proves that oil communities in this area (Afam) impacted negatively on the soil. The control site appeared to be unpolluted except TOC (6.8721) that showed extreme pollution. The result so far showed that oil activity has impacted on the soil since THC and TPHC which are one of the index elements were extremely higher in the study site than in the control.

\section{The quality of soil particle size distribution}

Using the percentage mean values in Table 5, clay in active soil decreased from top (0 to $15 \mathrm{~cm})$ to down $(15$ to $30 \mathrm{~cm})$ while silt and sand particles showed increase in percentage from top to down, contrary to control, whose silt and sand particles decrease in size as opposed to clay which increases from top to down. Comparing these results with those of physicochemical parameters in Table 5, it can be observed that these parameters are more concentrated in active soil which contains more of clay particle than in control. Cation exchange capacity of the soil increases with percentage clay and organic matter and the $\mathrm{pH}$ buffering capacity of a soil. Clay being the active portion of the soil matrix naturally accumulates more particles/materials than any other soil type (Ukah et al. 2019b, 2020b). High clay content in the study area is typical geology of Afam thus ensures the retention of petroleum hydrocarbon in the soil (Okoro et al. 2011). This might be the reason behind the insignificant concentration of O\&G and TPHC in groundwater even when the concentrations in the study soil were actually higher than other parameters.

\section{Conclusion}

Assessment of physicochemical qualities of groundwater and soils around Oil Producing communities in Afam, area of Port Harcourt, Niger Delta Nigeria has been carried out using, geo-accumulation and water quality indexes. Result from the physicochemical parameters, statistical analysis, WQI, I-geo calculations and particle size distribution showed that, $\mathrm{pH}$ and $\mathrm{Cu}$ did not correlate strongly with any of the parameters analyzed in the study. At 2-tailed of 0.05 levels the parameters correlate as follows: moderate correlation exist between $\mathrm{DO}$ and $\mathrm{Ca}>\mathrm{Na}$; strong to moderate correlation exist between temperature and TDS $>$ E.C $>\mathrm{Na}$ 
Fig.3 Geo-accumulation Index of the soil samples

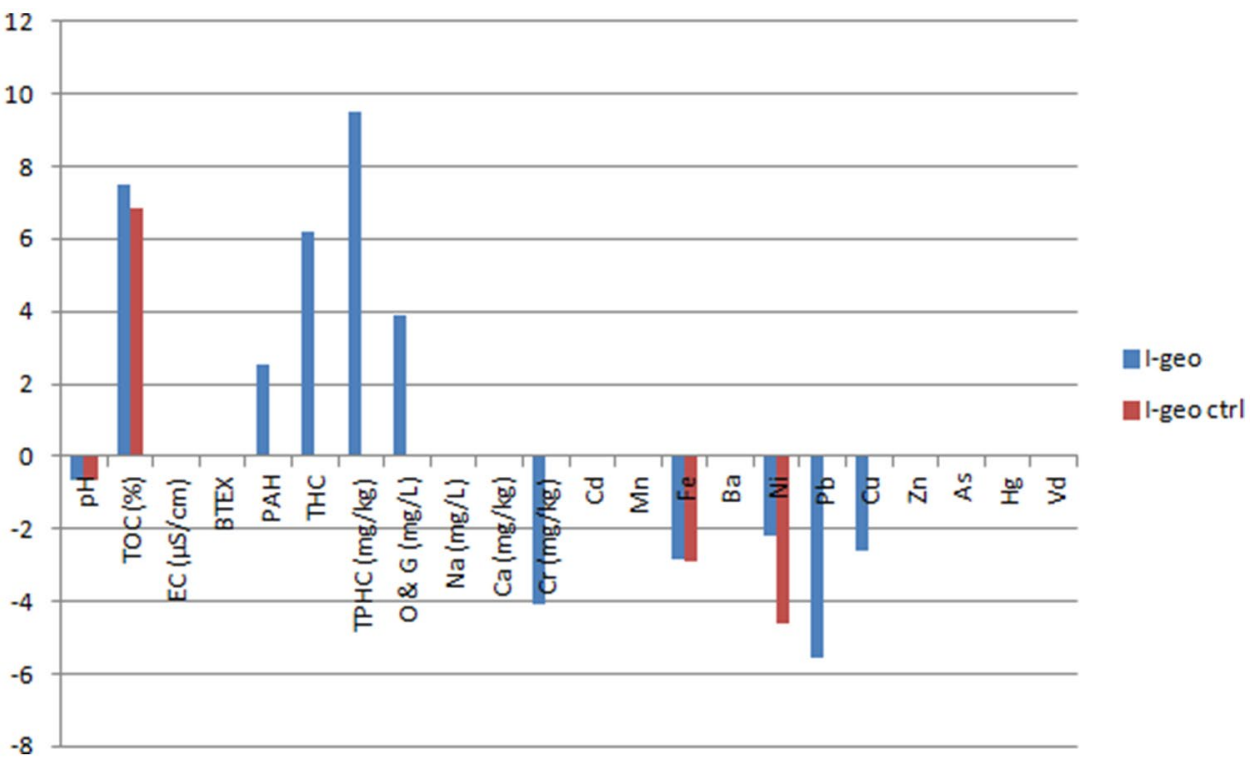

Table 5 Soil particle size distribution

\begin{tabular}{lrllll}
\hline Parameter & Depth $(\mathrm{cm})$ & A.S (range) & A.S \% & Ctrl range & Ctrl \% \\
\hline Clay (\%) & $0-15$ & $3.04-27.31$ & 18.8 & $7.07-7.17$ & 7.0 \\
& $15-30$ & $1.25-21.34$ & 14.0 & $7.55-7.6$ & 7.4 \\
Silt (\%) & $0-15$ & $57.53-86.97$ & 60.0 & $69.17-69.57$ & 70 \\
& $15-30$ & $56.44-95.22$ & 62.0 & $66.12-70.41$ & 68.4 \\
Sand (\%) & $0-15$ & $4.65-30.71$ & 21.2 & $22.81-23.02$ & 24.2 \\
& $15-30$ & $5.02-36.16$ & 24.0 & $21-24.87$ & 23.0 \\
\hline
\end{tabular}

A.S active soil, $C$ trl control

and $\mathrm{Ca}$. whereas at 2-tailed level of 0.02 the following correlations exist among the parameters: very strong correlation exist between E.C and TDS (0.988), $>\mathrm{Na}(0.966),>\mathrm{Ca}$ (0.957). TDS in turn is strongly correlated with $\mathrm{Na}$ (0.987), $>\mathrm{Ca}(0.972)$. Fe, $\mathrm{Zn}, \mathrm{Pb}$ and $\mathrm{Cr}$ TPHC, O\&G in the water samples were insignificant, $(<0.001 \mathrm{mg} / \mathrm{l})$ thus did not correlate with any of the physicochemical elements in the samples. At 2-tailed levels of 0.02 and 0.05 , no significant correlation exists between alkalinity and salinity of the water samples and also with any of the physicochemical parameters in the water samples. Groundwater showed excellent water quality except one, $\mathrm{BH} 2$ and $\mathrm{BH} 6$ (58.596 and 58.660, respectively) showed fair WQI. The significant of this is that not all the groundwater in area (Afam) can be used for drinking. $\mathrm{pH}, \mathrm{Cr}, \mathrm{Fe}, \mathrm{Ni}, \mathrm{Pb}$ and $\mathrm{Cu}$ in the soil were unpolluted since I-geo values are less than 1. PAH (2.5194) showed low pollution, O\&G (3.8886) showed moderate pollution, while THC (6.2069), TOC (7.4919) and TPHC (9.4851) showed extreme pollution. This result also proves that oil communities in this area (Afam) impacted negatively on the soil. The control site appeared to be unpolluted except TOC (6.8721) that showed extreme pollution. The result so far showed that oil activity has impacted on the soil since THC and TPHC which is one the index elements is extremely high in the study than in the control. Percentage of clay particles in the soil is higher than in control this might be the reason for more concentration of physicochemical elements in the soil. Cation exchange capacity of the soil increases with percentage clay and organic matter and the $\mathrm{pH}$ buffering capacity of a soil. High clay content in the study area is typical geology of Afam thus ensures the retention of petroleum hydrocarbon in the soil. This might be the reason behind the insignificant concentration of O\&G and TPHC in groundwater even when the concentrations in the soil were actually higher than other parameters.

Acknowledgements Authors appreciate members of the Environmental and Engineering Geology group of the University of Nigeria, Nsukka, Enugu State, Nigeria for their contributions and insights during the course of this research. We are especially happy at the effort and hard work the laboratory analysts/technicians put into this research.

Funding No the funding is provided for this research.

\section{Declarations}

Conflict of interest The authors declare there is no conflict of interest whatsoever.

Open Access This article is licensed under a Creative Commons Attribution 4.0 International License, which permits use, sharing, adaptation, distribution and reproduction in any medium or format, as long as you give appropriate credit to the original author(s) and the source, provide a link to the Creative Commons licence, and indicate if changes were made. The images or other third party material in this article are included in the article's Creative Commons licence, unless indicated otherwise in a credit line to the material. If material is not included in

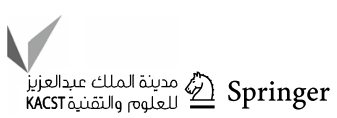


the article's Creative Commons licence and your intended use is not permitted by statutory regulation or exceeds the permitted use, you will need to obtain permission directly from the copyright holder. To view a copy of this licence, visit http://creativecommons.org/licenses/by/4.0/.

\section{References}

Akintola JO (1986) Rainfall distribution in Nigeria 1892-1983. Impact publishers Nig Ltd, Ibadan, p 58p

Anderson TA, Guthrie EA, Walton BT (1993) Bio-remediation in rhizosphere. Environ Sci Technol 27:2630-2636

Anoop S, Debashish H (2020) Fruit crops under nutrient-capped scenario: a timeless journey. Curr Hortic 8:14-17. https://doi.org/10. 5958/2455-7560.2020.00014.X

ASTM (2011) Standard practice for classification of soils for engineering purposes (Unified soil classification system). Designation: D 2487-06.

Bona C, Mendonça de Rezende I, Santos GO, Antonio de Souza L (2011) Effect soil contaminated by diesel oil on the germination of seeds and growth ofschinus terebinthifolius Raddi (Anacardiaceae) seedlings. Braz Arch Biol Technol 54:6

British Standard (B.S.) (1981) Universal Soil Classification System (USCS), Code of Practice for Site Investigation

British Standard (BS) (1986) Code of Practice for Foundations. British Standard Institution BS 8004

Bronson KF, Booker JD, Offcer SJ, Lascano RJ, Maas SJ, Searcy SW, Booker J (2005) Apparent electrical conductivity, soil properties and spatial covariance in the U.S. southern high plains. Precis Agric 6:297-311. https://doi.org/10.1007/s11119-005-1388-6

Brown RICE, McClellan NI, Deinniger RA et al (1972) A water quality index crashing physiological barrier. Indic Environ Qual $1: 173-182$

Chang C, Sommerfeldt TG, Carefoot JM, Schaalje GB (1983) Relationship of electrical conductivity with total dissolved salts and cation concentration of sulfate-dominated soil extracts. Can J Soil Sci 63:79-86

Department of Petroleum Resources (DPR) (2002) Environmental guidelines and standards for the petroleum industry in Nigeria, Revised. Ministry of Petroleum and Natural Resources, Abuja

Dieter CA, Maupin MA, Caldwell RR, Harris MA et al (2018) Estimated use of water in United State in 2015. Geol Soc Circ 1441:65

Edema N (2012) Effect of crude oil contaminated water on the environment, crude oil emulsions-composition stability and characterization. Prof Manar El-Sayed Abdul-Raouf (Ed). ISBN: 978-053-51$0220-5$, in Tech

Egbe RE, Thompson D (2010) Environmental challenges of oil spillage for families in oil-producing communities of Niger Delta region. JHER 13:24-33

Fondriest Staff (2010) What is conductivity? Environemtap Monitor. www.fondriest.com.retrieved on 1st of March 2020

Gayathiri E, Bharathi B, Selvadhas S, Natarajan S (2017) Analysis of physiochemical parameters of hydrocarbon contaminated soil. Int J Curr Res 9(2):46056-46059

Gentili R, Ambrosini R, Montagnani C, Caronni S, Citterio S (2018) Effect of soil $\mathrm{pH}$ on the growth, reproductive investment and pollen allergenicity of Ambrosia artemisiifolia L. Plant Sci, Front. https://doi.org/10.1007/s40808-020-00731-y

Gobo AE (1990) Rainfall data analysis as an acid for maximum drainage and flood control works in port harcourt. J Discov Innov 2(4):25-31

Keller EA (2011) Environmental geology, 9th edn. Pearson Education, New Jersy
Koppen W (1900) Versuch einer Klassifikation der Kilmate, vorzugsweise nach ihren Beziehungen zur Pflanzenwelt. Geogr Zeitschr 6(593-611):657-679

Labud V, Garcia C, Hernandez T (2007) Effect of hydrocarbon pollution on the microbial properties of a sandy and a clay soil. Chemosphere 66(10):1863-1871

Lenntech (2017) Why oxygen dissolved in water is important. www. lenntech.com Retrieved from on 30th April 2020.

Li P, Qian H, Wu J (2010) Groundwater quality assessment based on improved water quality index in Pengyang County, Ningxia, North west China. J Chem 7:209-216

Mahmood B, Najah A, Haiyan S (2020) Optimization of oxytetracycline sorption onto iron modified montmorillonite. IOP Conf Ser Mater Sci Eng 737:012207. https://doi.org/10.1088/1757-899X/ 737/1/012207

Merki JP (1970) Structural geology of the cenozoic Niger Delta. African Geology. University of Ibadan Press, pp251-268

Mukherjee AK, Bordoloi NK (2010) Bioremediation and reclamation of soil of petroleum hydrocarbon and heavy metal content of soil affected by Ebocha oil spillage in Niger Delta, Nigeria. J Environ Mgt 79:133-139

Muller G (1969) Index of geoaccumulation in sediments of the Rhine river. Geol J 2(3):108-118

Murat RC (1970) Stratig raphy and Paleogeography of the Cretaceous and Lower Teriary in Southern Nigeria. In: Dessauvagie TTJ, Whiteman AJ (eds) African geology. University of Ibadan Press, Ibadan, pp 251-266

Nduka JK, Orisakwe OE (2011) Water-quality issues in the Niger Delta of Nigeria: a look at heavy metal levels and some physicochemical properties. Environ Sci Pollut Res 2011(18):237-246. https://doi. org/10.1007/s11356-010-0366-3

Nduka JK, Orisakwe OE, Ezenweke LO (2008) Some physicochemical parameters of potable water supply in Warri, Niger Delta area of Nigeria. Sci Res Essay 3(11):547-551

Ngah SA (2009) Deep aquifer systems of eastern Niger Delya: their hydrogeological properties, groundwater chemistry and vulnerability to degradation. Unpublished Ph.D. Thesis, Rivers State University of Science and Technology. Port Harcourt, Nigeria

Nwachukwu AN, Osuagwu JC (2014) Effect of oil spillage on groundwater qulity in Nigeria. Am J Eng Res 3(6):271-274

Nwankwoala HO, Walter IO (2012) Assessment of groundwater quality in shallow coastal aquifers of Okrika Island, Eastern Niger Delta. Nigeria. Ife J Sci 14(2):297

Okoro D, Oviasogie PO, Oviasogie FE (2011) Soil quality assessment 33 months after crude oil spillage and clean-up. Chem Speciat Bioavailab 23(1):1-6

Osuji LC, Onojake CM (2004) The Ebocha-8 oil Spill II. Fate of associated heavy metals six month. AJEAM-RAGEE 9:78-87

Osuji LC, Udoetok IA, Ogali RE (2006) Attenuation of petroleum hydrocarbons by weathering: a case study. Chem Biodiv 3:422-433

Ou SM, Zheng JH, Richardson BJ, Lam PSK (2004) Petroleum hydrocarbons and polycyclic aromatic hydrocarbons in the surficial sediments of Xiamen Haror and Yaun Dan lake, China. Chemosphere 56:107-112

Peralta NR, Costa JL (2013) Delineation of management zones with soil apparent electrical conductivity to improve nutrient management. Comp Electron Agric 99:218-226. https://doi.org/10.1016/j. compag.2013.09.014

Rabenberg G, Kniffen C (2014) Electrical conductivity: the pulse of the soil. Soil Works LLC, 4200 W. 8th St., Yankton, SD 57078, 605-260-0784

Racine CH (1994) Long-term recovery of vegetation on two experimental crude oil spills in interior Alaska black spruce taiga. Can J Bot 72:1171-1177 
Reyment RA (1965) Aspects of the geology of Nigeria. The stratigraphy of the cretaceous and cenozoic deposits. Ibadan University Press, pp 23-73

Richard WL, David DS (1970) System study of oil spill clean-up procedure. Presented in Fall Meeting of the Society of Petroleum Engineers of AIME. Houston, Texas, USA

Short RC, Stouble AJ (1967) Outline of Geology of the Niger-Delta. Bull Assoc Am Pet Geol 54(5):276-779

Soltani S, Asghari Moghaddam A, Barzegar R, Kazemian N, Tziritis E (2017) Hydrogeochemistry and water quality of the KordkandiDuzduzan plain, NW Iran: application of multivariate statistical analysis and PoS index. Environ Monitor Assess 189:455

Sudduth KA, Kitchen NR, Wiebold WJ, Batchelor WD, Bollero GA, Bullock DG, Clay DE, Palm HL, Pierce FJ, Schuler RT, Thelen KD (2005) Relating apparent electrical conductivity to soil properties across the north-central USA. Comput Electron Agric 46:263-283. https://doi.org/10.1016/j.compag.2004.11.010

Sutton NB, Maphosa F, Morillo JA et al (2013) Impact of long-term diesel contamination on soil microbial community structure. Appl Environ Microbiol 79(2):619-630

Toro D, Dominic MM, Joy AS, William A (2007) Predicting the toxicity of neat and weathered crude oil: toxic potential and the toxicity of saturated mixtures. Environ Toxicol Chem 26(1):24-36

Townsend GT, Prince RC, Suflita JM (2003) Anaerobic oxidation of crude oil hydrocarbons by the resident microorganisms of a contaminated anoxic aquifer. Environ Sci Technol 37(22):5213-5218

Ukah BU, Igwe O, Ameh P (2018) The impact of industrial wastewater on the physicochemical and microbiological characteristics of groundwater in Ajao-Estate Lagos, Nigeria. Environ Monit Assess 190:235

Ukah BU, Igwe O, Ubido OE (2019) Influence of soil particle size distribution on groundwater quality around industrial areas of Oshodi-Lagos Nigeria. J Water Soil Sci. https://doi.org/10.36959/ $624 / 435$
Ukah BU, Egbueri JC, Unigwe CO, Ubido OE (2019a) Extent of heavy metals pollution and health risk assessment of groundwater in a densely populated industrial area, Lagos, Nigeria. Int J Energy Water Res. https://doi.org/10.1007/s42108-019-00039-3

Ukah BU, Ubido OE, Igwe O (2020) Geo-statistical assessment of the soil quality and its influence on groundwater pollution in some part of Lagos State Nigeria. Model Earth Syst Environ. https:// doi.org/10.1007/s40808-020-00731-y

Ukah BU, Ameh PD, Egbuer JC, Unigwe CO, Ubido OE (2020) Impact of effluent-derived heavy metals on the groundwater quality in Ajao industrial area, Nigeria: an assessment using entropy water quality index (EWQI). Int J Energy Water Res. https://doi.org/10. 1007/s42108-020-00058-5

US EPA Method 8015B (1986) Total petroleum hydrocarbons (TPH) analysis gasoline and diesel fuel

US EPA Method 8020B (1992) GC/MS gas chromatography-mass spectrometry

US EPA Method 9071A (1994) Oil and grease-extraction for sludge and sediments. EPA Report SW-846, Chapter 5

Wang X, Feng J, Zhao J (2009) Effect of crude oil residuals on soil chemical properties in oil sites, Momoge wetland, China. Environ Monit Assess 161(1-4):271-280

WHO (2017) Guidelines for drinking water quality (4th ed.). First Addendum. Switzerland eneva: World Health Organization. ISBN 978-92-4-154995-0

Wu J, Li P, Qian H (2011) Groundwater quality in Jingyuan County, a semi-humid area in Northwest China. J Chem 8(2):787-793

Publisher's Note Springer Nature remains neutral with regard to jurisdictional claims in published maps and institutional affiliations. 